DOI: https://doi.org/10.32838/2523-4803/69-6-32

УДК 338.47.656.2

\title{
Мельник Т.C.
}

кандидат економічних наук,

начальник відділу прогнозування ризиків,

Департаменту оперативного моніторингу,

Акціонерне товариство «Українська залізниця»

\section{Melnyk Tatyana}

Operational Monitoring Department,

Ukrainian Railways Joint Stock Company

\section{ТЕХНОЛОГІЯ КОМПЛЕКСНОГО}

\section{МАРКЕТИНГОВОГО ДОСЛІДЖЕННЯ ПІД ЧАС \\ ЦІЛІСНОГО УПРАВЛІННЯ СПОЖИВЧОЮ ЦІННІСТЮ ЗАЛІЗНИЧНИХ ПАСАЖИРСЬКИХ ПЕРЕВЕЗЕНЬ}

Низька ефективність заходів, вживаних для підвищення якості обслуговування $і$ задоволення клієнтів залізниці, підштовхнула до пошуку відмінних від наявних методів вивчення пасажирів, їхніх запитів, способів задоволення. Обтрунтовано потребу в розвитку наявної методологї маркетингових досліджень. Наведено удосконалену технологію комплексного маркетингового дослідження ринку залізничних пасажирських перевезень з урахуванням особливостей пропонованих на ньому послуг. Для потреб цілісного управління споживчою цінністю таких послуг сегментування транспортного ринку рекомендовано проводити за методом «k-сегментування». Метод адаптовано до галузевої спецุифіки та розвинуто завдяки пропонуванню нових ознак сегментаиії пасажирів. Переваги та ефективність розробленої методики під час формування споживчої иінності транспортної послуги доведено на конкретному прикладі.

Ключові слова: залізничний пасажирський транспорт, методологія маркетингових досліджень, технологія комплексного маркетингового дослідження, сегментування споживачів, ознаки сегментаиії, споживча ичінність транспортної послуги, переваги та ущемлення пасажирів. 
Постановка проблеми. Необхідність маркетингових досліджень для успішної діяльності на будь-якому ринку сьогодні вже не викликає сумнівів у керівників вітчизняних підприємств, оскільки саме вища керівна ланка найбільше зацікавлена в отриманні адекватної інформації для вироблення виважених та обгрунтованих управлінських рішень. Беззаперечним $є$ й той факт, що маркетингові дослідження ринків послуг набагато складніші, ніж дослідження товарних ринків.

Транспортні послуги для населення займають особливе місце серед всіх інших послуг, а послуги з перевезення пасажирів залізничним транспортом на далекі відстані характеризуються такою низкою специфічних відмінностей, що їх можна назвати унікальним продуктом, який фактично не має аналогів. Специфіка цих послуг накладає відбиток як на управління їх споживчою цінністю, так і на маркетингові дослідження, що мають надавати інформацією для такого управління.

Збитковий характер залізничних пасажирських перевезень, який набув хронічної форми, не дає можливості розвивати належним чином цей вид перевезень. Це стає головною причиною недоотримання прибутків від пропонування населенню транспортної послуги, яка не відповідає повною мірою очікуванням споживачів.

Надання пасажирам транспортної послуги з потрібними (запитуваними) характеристиками неможливе без відповідного інформаційного забезпечення, яке здатні виробити лише маркетингові дослідження, здійснювані за новою методологією, що базується на відмінних від наявних принципах, технологіях, техніках, методах і методиках. Отже, потреба у розвитку методології маркетингових досліджень послуги з перевезень пасажирів залізничним транспортом далекого сполучення зумовила актуальність цієї статті.

Аналіз останніх досліджень i публлікацій. Проблеми теорії і методології маркетингових досліджень на різних ринках розглядаються у працях таких відомих вітчизняних та іноземних науковців, як Є.П. Голубков, С.О. Зозульов, Ф. Котлер, Н.К. Малхотра, Г.А. Черчилль, А.О. Старостіна, А.В. Федорченко та ін. Роль маркетингової інформації у маркетингових дослідженнях висвітлюється в низці публікацій останніх років І.К. Беляєвського, В.Н. Голоскокова, Т.П. Данька, В.П. Клепікова, Е.В. Новаторова, В.С. Телятнікової та інших сучасних авторів.

Теоретичні основи залізничного пасажирського маркетингу закладено в працях В.Г. Галабурди, О.В. Єлізар'єва, В.О. Мілевської, інших зарубіжних дослідників, а також вітчизняних науковців І.М. Аксьонова, О.В. Бакалінського, Г.Д. Ейтутіса, I.О. Жарської, М.А. Окландера, О.В. Христофора та ін. При цьому методологія маркетингових досліджень, яка була би здатна забезпечити менеджмент залізничної галузі інформацією, потрібною для ефективного управління пасажирськими перевезеннями, в режимі сьогодення, коли необхідно здійснити стрибкоподібне зростання споживчої цінності послуг залізниці задля виведення іiі з досить важкого стану, до цього часу не виступала предметом окремих досліджень.

Формулювання цілей статті. Метою статті є удосконалення існуючої технології маркетингових досліджень в контексті оновлення їх методології, що має підвищити практичну значущість результатів маркетингових досліджень для потреб цілісного управління споживчою цінністю транспортного обслуговування клієнтів залізничного пасажирського транспорту далекого сполучення, яке $\epsilon$ необхідною умовою максимізації задоволення пасажирів, а отже, й зростання обсягів перевезень та споживання ними додаткових послуг.

Виклад основного матеріалу дослідження. Технологія комплексного маркетингового дослідження, крім інших обов'язкових етапів, включає сегментацію ринку $з$ iii наступним застосуванням для структурування реальних і потенційних споживачів послуг, які виступають об'єктами конкретного маркетингового дослідження [1, с. $60-81 ; 3$, с. $45-46$; 5, с. $110-131$; 6 , с. $74-78 ; 7$, с. $23-26 ; 8$, с. 111-116]. Однак існуюча сегментація за традиційними ознаками не адаптована до специфіки транспортного ринку та послуги з перевезення пасажирів залізницею в далекому сполученні. Крім того, наявна методологія не виділяє окремим етапом кластеризацію, яка дає змогу сформувати однорідні поведінкові групи на ринку транспортних послуг, що є дуже важливим при одночасному обслуговування великої кількості клієнтів у спільному просторі.

Маркетингові дослідження щодо соціального портрету пасажирів, складеного на підставі традиційних ознак сегментації, проводились маркетологами пасажирського сектору залізничного транспорту систематично, починаючи з 2012 р., з періодичністю два разі на рік. Проте вони давали лише осереднене уявлення про пасажирів, а їх цикл дозволяв побачити загальні тенденції у зміні соціальних характеристик споживачів послуг. Вагомої користі для менеджменту пасажирського сектору залізниці у вирішенні зазначених вище проблем така інформація не приносить. Отримані дані не дають змоги навіть скласти прогнози щодо можливих обсягів і зміни напрямків пасажиропотоків.

3 двох існуючих у світовій практиці підходів до сегментування $[2$, с. $5-6 ; 4$, с. $101 ; 9$, с. $184-186 ; 10$, с. 26] метод «a priori» (апріорний) застосовуються, коли сегментні групи сформовані завчасно, а сегментування не $\epsilon$ частиною поточного дослідження і виступає лише допоміжним базисом вирішення інших маркетингових завдань. Тому будемо застосовувати метод «post hoc» (апостеріорний), за якого припускається невизначеність ознак сегментування і сутності сегментів.

За умови багатомірної класифікації споживачів послуг залізничного пасажирського транспорту далекого сполучення в межах підходу «post hoc» найбільш правильно буде застосувати метод «k-сегментування», який розглядає споживчий ринок 3 невизначеною структурою у розрізі ознак, що вивчаються.

Метод «К-сегментування» пропонуємо здійснювати за такими послідовними етапами: 
1) визначення можливих ознак сегментування, задля чого нами було здійснено цикл маркетингових досліджень на теми «Соціальний портрет пасажирів залізничного транспорту», «Переваги пасажирів при виборі типу вагону» та «Імідж вітчизняного залізничного транспорту». Ними стали: вік; рід занять; цілі поїздок; частота поїздок; тип вагону; напрям пошуку споживчої цінності»; наміри щодо поїздок залізничним транспортом;

2) за виділеними ознаками сегментації пасажирів сформовано відповідний масив даних (підсумковий обсяг вибірки - 20164 респондентів) у формі таблиці формату «Excel», в який у стовбцях зазначаються питання (ознаки сегментації), а у рядках - порядкові номери відповідей (рис. 1).

У цьому прикладі номери відповідей респондентів означають:

- вік: «1» - до 18 років; «2» - від 18 до 23 років; «3» - від 24 до 39 років; «4» - 40 до 54 років; «5» - від 55 до 60 років; «6» - понад 60 років;

- рід занять: «1» - підприємець; «2» - керівник; «3» - фахівець, робітник, службовець; «4» - студент, учень; «5» - домогосподарка; «6» - тимчасово не працюючий, «7»- пенсіонер;

- цілі поїздок: «1»- робота, бізнес; «2»- особисті справи (відвідування родичів, друзів тощо); «3» - відпочинок; «4» - відрядження; «5» - навчання;

- частота поїздок: «1» - щотижнево; «2» - щомісячно; «3»- кілька разів на рік; «4» - раз в рік і рідше;

- тип вагону: «1»- СВ; «2»-1 клас сидячого типу; «3»-2 клас сидячого типу; «4»- купе; «5»- плацкарт;

- напрям пошуку споживчої цінності (СЦ): «1»ущемлення не влаштовують, переваги не влаштовують (У-, П-); «2»- ущемлення не влаштовують, переваги влаштовують $(\mathrm{У}-$, П+); «3» - ущемлення влаштовують, переваги не влаштовують (У+, П-); «4»- ущемлення влаштовують, переваги влаштовують $(\mathrm{У}+, \Pi+)$;
- наміри щодо поїздок залізницею: «1» - «відмовлюсь»; «2» - «скоріше, відмовлюсь»; «3»- «звернусь у крайньому випадку / за відсутності кращого варіанту»; «4»- «скоріше, скористаюсь»; «5»- «скористаюсь обов'язково»;

3) виходячи $з$ того, що стійка сегментна група формується на перетині двох ознак сегментації, з набору досліджуваних ознак на підставі розрахунку математичних коефіцієнтів кореляції виокремлюємо ті, між якими існує парна кореляція, яка буде свідчить про можливість спільного застосування цих ознак сегментації пасажирів (рис. 2);

4) на підставі виявлених попарних кореляцій між вагомими ознаками сегментації пасажирів, перегруповуючи результати вказаних вище польових маркетингових досліджень, формуємо сегментні групи і визначаємо їх ємність за кількістю респондентів. За результатами такого перегрупування будуємо таблиці парних кореляцій ознак сегментації, між якими виявили вагомий зв'язок, а саме: «напрям пошуку споживчої цінності» - «тип вагону» (рис. 3), «цілі поїздок» - «наміри» (таблиця, аналогічна наведеній на рис. 3), «напрям пошуку споживчої цінності» - «наміри» (таблиця, аналогічна наведеній на рис. 3). Зв'язок між ознаками «рід занять» і «цілі поїздок» не розглядаємо, оскільки він не відповідає цілям наукового пошуку в даній роботі і не представляє практичної цінності.

За сформованими таблицями розраховуємо відсоток респондентів, що опинились у певній сегментній групі, та виділяємо групи з вагомим відсотком, які зводимо в табл. 1;

5) на завершальному етапі «k-сегментування» формулюємо сегменти, які підлягають критеріальній оцінці на перспективність (за загальноприйнятими показниками місткості, прибутковості, доступності, істотності, сумісності), опису з присвоєнням умовних маркетингових назв та подальшій з ними роботі маркетологів.

\begin{tabular}{|c|c|c|c|c|c|c|c|c|}
\hline \multicolumn{7}{|c|}{ Дані для k-сегментування: Таблиця 1.sta*(7v*20164c) } & $\square$ & < \\
\hline \multirow[b]{2}{*}{$\begin{array}{c}\text { Номери } \\
\text { відповідей }\end{array}$} & \multicolumn{7}{|c|}{ Змінна (ознаки сегментації) } & \multirow{2}{*}{$\Delta$} \\
\hline & вІк & РІД ЗАнять & ццлл поїздок & $\begin{array}{l}\text { ЧАСТОТА } \\
\text { ПОÏ̈ДОК }\end{array}$ & ТИП ВАГОНУ & $\begin{array}{c}\text { НАПРЯМИ } \\
\text { ПОШУКУ СЦ }\end{array}$ & $\begin{array}{l}\text { НАМІРИ } \\
\text { ЩОДО } \\
\text { ПОЇЗДОК } \\
\text { ЗАЛІЗНИЦЕЮ }\end{array}$ & \\
\hline 1 & 1 & 3 & 4 & 3 & 5 & 1 & 5 & \\
\hline 2 & 6 & 3 & 1 & 3 & 3 & 1 & 4 & \\
\hline 3 & 5 & 1 & 5 & 4 & 5 & 3 & 2 & \\
\hline 4 & 2 & 3 & 1 & 3 & 5 & 4 & 1 & \\
\hline 5 & 2 & 2 & 2 & 2 & 4 & 2 & 3 & \\
\hline 6 & 3 & 4 & 4 & 4 & 1 & 4 & 5 & \\
\hline 7 & 4 & 7 & 3 & 1 & 2 & 3 & 4 & $\nabla$ \\
\hline & & & & & & & 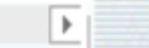 & \\
\hline
\end{tabular}

Рис. 1. Зовнішній вигляд масиву вхідних даних для «k-сегментування»

Джерело: побудовано автором 


\begin{tabular}{|c|c|c|c|c|c|c|c|c|}
\hline \multicolumn{7}{|c|}{ Робоча.stw - Кореляції (Таблиця1.sta) } & $\square$ & $x$ \\
\hline \multirow[t]{2}{*}{ ЗМाHHA } & \multicolumn{7}{|c|}{$\begin{array}{l}\text { Кореляції (Таблиця } 1 . \text { sta) } \\
\text { Відмічені кореляції значимі на рівні } p<, 05000 \\
\mathrm{~N}=20164\end{array}$} & \multirow[t]{2}{*}{ 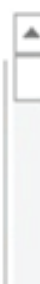 } \\
\hline & BIK & РІД ЗАНЯТЬ & $\begin{array}{c}\text { ㅆл } \\
\text { поїздок }\end{array}$ & $\begin{array}{l}\text { ЧАСТОТА } \\
\text { ПОÏ̈ДОК }\end{array}$ & $\begin{array}{c}\text { ТИП } \\
\text { вАГОНУ }\end{array}$ & $\begin{array}{l}\text { НАПРЯМИ } \\
\text { ПОШУКУ } \\
\text { СЦ }\end{array}$ & $\begin{array}{l}\text { НАМІРИ } \\
\text { ЩОДО } \\
\text { ПОЇЗДОК } \\
\text { ЗАЛІЗНИ- } \\
\text { ЦЕЮО }\end{array}$ & \\
\hline BIK & 1 & $-0,12$ & 0,06 & $-0,06$ & 0,20 & 0,11 & 0,08 & \\
\hline РІД ЗАНЯТЬ & $-0,12$ & 1,00 & 0,29 & 0,10 & 0,18 & 0,19 & $-0,09$ & \\
\hline цاІлІ поїздок & 0,06 & 0,29 & 1,00 & 0,16 & $-0,07$ & 0,22 & 0,46 & \\
\hline ЧАСТОТА ПОӤЗДОК & $-0,06$ & 0,10 & 0,16 & 1,00 & 0,26 & 0,10 & $-0,03$ & \\
\hline ТИП ВАГОНУ & 0,20 & 0,18 & $-0,07$ & 0,26 & 1,00 & 0,63 & $-0,09$ & \\
\hline НАПРЯМИ ПОШУКУ СЦ & 0,11 & 0,19 & 0,22 & 0,10 & 0,63 & 1,00 & 0,40 & \\
\hline НАМІРИ ЩОДО ПОӤЗдОК & 0,08 & $-0,09$ & 0,46 & $-0,03$ & $-0,09$ & 0,40 & 1,00 & $\nabla$ \\
\hline & & & & 1 & & & 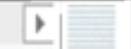 & \\
\hline
\end{tabular}

Рис. 2. Зовнішній вигляд таблиці попарного обчислення коефіціснтів кореляції між ознаками сегментації пасажирів залізничного транспорту

Джерело: розраховано автором

\begin{tabular}{|c|c|c|c|c|c|c|c|}
\hline \multicolumn{6}{|c|}{ Робоча.stw - Спостер. част.: Напрями пошуку СЦ ... } & $\square$ & X \\
\hline \multirow{2}{*}{$\begin{array}{c}\text { Напрям } \\
\text { пошуку } \\
\text { Сц }\end{array}$} & \multicolumn{6}{|c|}{$\begin{array}{l}\text { Спостер. част.: Напрями пошуку СЦ за типами вагонів } \\
\text { (Таблиця1.sta) }\end{array}$} & \multirow[t]{2}{*}{\begin{tabular}{|c|c|c} 
\\
\end{tabular}} \\
\hline & $\begin{array}{c}1 \\
(\mathrm{CB})\end{array}$ & $\begin{array}{c}2 \\
(1 \text { клас) }\end{array}$ & $\begin{array}{c}3 \\
(2 \mathrm{kлас)})\end{array}$ & $\begin{array}{c}4 \\
\text { (купе) }\end{array}$ & $\begin{array}{c}5 \\
\text { (плацкарт) }\end{array}$ & РАЗОМ & \\
\hline $1(\mathrm{y}-, \mathrm{n}-)$ & 88 & 486 & 1060 & 1099 & 1506 & 4239 & \\
\hline $2(y-, \Pi+)$ & 1144 & 1730 & 303 & 398 & 253 & 3828 & \\
\hline $3(y+, n-)$ & 2282 & 1124 & 213 & 195 & 419 & 4233 & \\
\hline $4(y+, \pi+)$ & 3984 & 2441 & 418 & 389 & 632 & 7864 & \multirow{3}{*}{$\rightarrow$} \\
\hline Bcboro: & 7498 & 5781 & 1994 & 2081 & 2810 & 20164 & \\
\hline & & & \multicolumn{3}{|c|}{$\vdots 1$} & 5 & \\
\hline
\end{tabular}

Рис. 3. Зовнішній вигляд таблиці з групами пасажирів, утвореними на перетині ознак сегментації «напрям пошуку споживчої цінності» - «тип вагону»

Джерело: сформовано і розраховано автором

В розглянутому прикладі нами сформовано 15 таких сегментів, а саме: «простаки», «компромісні», «вибагливі», «обрані», «щасливчики», «зобов’язані», «підштовхнуті», «приречені», «повинні», «змушені», «лишенці», «ущемленці», «хиткі», «заручники», «прихильники». Для кожного сегменту сформульовано відповідну маркетингову стратегію створення споживчої цінності.

3 табл. 1 зрозуміло, що пильної уваги маркетологів потребують як задоволені, так і незадоволені пасажири. Зокрема, пасажири-»простаки», що здійснюють поїздку вагонами плацкарт, де їх не влаштовують ущемлення і переваги, скоріше, відмовляться від повторних звернень до залізниці, якщо не збільшити споживчу цінність послуги для них; «компромісні» пасажири вагонів 1 класу сидячого типу, яких не влаштовують ущемлення в цих вагонах, підштовхують маркетологів до пошуку зменшення ущемлень задля упередження їх переходу на інші види і транспорту або дешевші типи рухомого складу; «вибагливі» пасажири вагонів СВ, яких не влаштовують переваги цих вагонів, скоріше, 
Питома вага виділених перспективних сегментів пасажирів залізниці транспорту, сформованих за методом «k-сегментування», \%

\begin{tabular}{|c|c|c|c|c|}
\hline Ознака сегментації & \multicolumn{4}{|c|}{ Ознака сегментації } \\
\hline Напрям пошуку споживчої & \multicolumn{4}{|c|}{ Тип вагону } \\
\hline цінності & CB & \multicolumn{2}{|l|}{1 клас } & Плацкарт \\
\hline У-, П- & $\mathrm{x}$ & \multicolumn{2}{|l|}{$\mathrm{x}$} & 7,5 \\
\hline $\mathrm{Y}-, \Pi+$ & $\mathrm{X}$ & \multicolumn{2}{|l|}{8,6} & $\mathrm{x}$ \\
\hline $\mathrm{y}+, \Pi-$ & 11,3 & \multicolumn{2}{|l|}{$\mathrm{X}$} & $\mathrm{x}$ \\
\hline $\mathrm{y}+, \Pi+$ & 19,7 & \multicolumn{2}{|l|}{12,1} & $\mathrm{x}$ \\
\hline \multirow{2}{*}{ Наміри щодо поїздок залізницею } & \multicolumn{4}{|c|}{ Цілі поїздок } \\
\hline & Робота, бізнес & Особисті справи & & Навчання \\
\hline Скоріше, скористаюсь & 10,7 & 11,7 & & $\mathrm{X}$ \\
\hline Обов'язково скористаюсь & 14,5 & 9,2 & & 8,2 \\
\hline \multirow{2}{*}{ Наміри щодо поїздок залізницею } & \multicolumn{4}{|c|}{ Напрям пошуку споживчої цінності } \\
\hline & У-, П- & \begin{tabular}{l|l}
$\mathrm{y}_{-}, \Pi+$ & $\mathrm{y}$ \\
\end{tabular} & $y+, \Pi-$ & $\mathrm{y}+, \Pi+$ \\
\hline Скоріше, скористаюсь & 9,1 & 8,0 & $\mathrm{x}$ & 9,6 \\
\hline Обов'язково скористаюсь & $\mathrm{x}$ & $\mathrm{x}$ & 9,0 & 25,0 \\
\hline
\end{tabular}

Джерело: розраховано і сформовано автором

будуть шукати інші варіанти здійснення поїздки, якщо не створити їм більші переваги у таких вагонах.

Сегменти пасажирів, яких влаштовують ущемлення і переваги («обрані» і «щасливчики», «хиткі» i «прихильники»), потрібно закріпити за залізничним транспортом, причому за більш дорогим типом рухомого складу, постійно дбаючи про те, щоб споживча цінність послуг у цих вагонах відповідала сподіванням пасажирів.

Такі сегментні групи, як «зобов’язані», «приречені», «повинні» і «змушені» пасажири, через цілі поїздок $є$ доволі стійкими та утворюють «ядро» цільової аудиторії послуг залізниці. Відносно них головне завдання маркетологів - не допустити скорочення сегментів, однак виявити передумови можливого витоку пасажирів цих сегментів та причини відмови від послуг залізниці без додаткових маркетингових досліджень $з$ наступною сегментацією за напрямом пошуку споживчої цінності (запропонована нами нова ознака) неможливо;

6) визначення перспективних сегментів та їх опис, 3 нашої точки зору, має знайти логічне завершення у визначенні векторів роботи маркетологів з цими сегментами, тобто у формуванні і реалізації відповідних маркетингових стратегій. Вважаємо, що цим додатковим етапом повинна завершуватись сегментація споживачів за методом «post hoc».

Для кожного виділеного нами сегменту пасажирів сформульовано відповідну маркетингову стратегію створення споживчої цінності, конкретизація яких у маркетингових планах та наступна реалізація створить умови для збільшення пасажиропотоку в далекому сполученні (включаючи міжнародне), що сприятиме підвищенню доходів від продажу основної і додаткових послуг.

Висновки. Запропонований метод сегментування пасажирів залізничного транспорту далекого сполучення, який базується на оновленій методології маркетингових досліджень, має такі важливі переваги, як відносна простота в отриманні інформації та реалізація диференційованого підходу до аналізу загального пасажиропотоку в далекому сполученні, завдяки чому стає можливим сформувати для кожного сегменту пасажирів послугу зі споживчою цінністю бажаної величини і змісту. Це дозволить створити умови для максимального наближення фактичної споживчої цінності наданих послуг до очікувань пасажирів і тим самим підвищити задоволення клієнтів залізниці.

\section{Список літератури:}

1. Зозулев А.В., Солнцев С.А. Маркетинговые исследования: теория, методология, статистика. Москва: Рыбари; Киев: Знання, 2008. 643 с.

2. Карасев А.П. Использование методики обратного сегментирования на примере рынка туристических услуг. Практический маркетинг. 2015. № 9. С. 3-14.

3. Ковальчук С.В., Петрицька О.С. Роль маркетингових досліджень у забезпеченні ефективної роботи підприємств легкої промисловості. Маркетинг і менеджмент інновацій. 2010. №1. С. 42-51.

4. Корпан О.С. Особливості сегментації ринку туристичних послуг як складової маркетингових досліджень. Вісник Хмельницького національного університету. 2015. № 3. С. 100-105.

5. Малхотра Нэреш К. Маркетинговые исследования. Москва: Вильямс, 2002. 1200 с.

6. Маркетинговые исследования. Теория и практика: учебник для прикладного бакалавриата / Под общ. ред. О.Н. Романенковой. Москва: Издательство Юрайт, 2014. 315 с.

7. Никишина Е.С. Методика проведения маркетингового исследования и сегментации рынка жилой недвижимости с учетом концепции совместного маркетинга. Экономика и бизнес: теория и практика. 2013. № 13. С. $22-28$. 
8. Полторак В.А. Маркетинговые исследования: сущность, методы, технологии. Социология: теория, методы, маркетинг. 2000. № 1. С. 108-128.

9. Саак А.Э., Пшеничных Ю.А. Маркетинг в социально-культурном сервисе и туризме. СПб.: Питер, 2007.480 с.

10. Шереметьева В.Н. Сегментирование в прямом маркетинге. Российское предпринимательство. 2005. № 3. C. $25-29$.

\section{References:}

1. Zozulyov A.V., Solntsev S.A. (2008) Marketingovyye issledovaniya: teoriya, metodologiya, statistika [Marketing research: theory, methodology, statistics]. Moskva: Rybari; Kiyev: Znannya, 643 p. (in Russian)

2. Karasyov A.P. (2015) Ispolzovaniye metodiki obratnogo segmentirovaniya na primere rynka turisticheskikh uslug [The use of reverse segmentation techniques on the example of the market of tourist services]. Prakticheskiy marketing Hands-on marketing, no. 9, p. 3-14. (in Russian)

3. Kovalchuk S.V., Petrytska O.S. (2010) Rol marketyngovykh doslidzhen u zabezpechenni efektyvnoyi roboty pidpryyemstv legkoyi promyslovosti [The role of marketing research in ensuring the efficient operation of light industry enterprises]. Marketyng I menedzhment innivatsiy - Marketing and innovation management, no. 1, p. 42-51. (in Ukrainian)

4. Korpan O.S. (2015) Osoblyvosti segmentatsiyi rynku turystychnykh poslug yak skladovoyi marketyngovykh doslidzhen [Features of the segmentation of the tourist services market as a component of marketing research]. Visnyk Khmelnttskogo natsionalnogo universytetu - Bulletin of Khmelnitsky National University, no. 3, p. 100-105. (in Ukrainian)

5. Malkhotra N.K. (2002) Marketingovyye issledovaniya [Marketing research]. Moskva: Vilyams, 1200 p. (in Russian)

6. Marketingovyye issledovaniya. Teoriya i praktika; uchebnik dlya prikladnogo bakalavriata [Marketing research. Theory and Practice: A Textbook for Applied Baccalaureate] / Under the total. ed. O.N. Romanenkova. Moskva: Izdatelstvo Yurayt, 2014, 315 p. (in Russian)

7. Nikishina Ye.S. (2013) Metodika provedeniya marketingovogo issledovaniya i segmentatsii runka zhiloy nedvizhimosti s uchetom kontseptsii sovmestnogo marketinga [Methodology for conducting marketing research and segmentation of the residential real estate market, taking into account the concept of joint marketing]. Ekonomika i biznes: teoriya i praktika Economics and business: theory and practice, no. 13, p. 22-28. (in Russian)

8. Poltorak V.A. (2000) Marketingovyye issledovaniya: sushchnost, metody, tekhnologii [Marketing research: essence, methods, technologies]. Sotsiologiya: teoriya, metody, marketing - Sociology: theory, methods, marketing, no. 1, p. $108-128$. (in Russian)

9. Saak A.E., Pshenichnykh Yu.A. (2007) Marketing v sotsialno-kulturnom servise i turizme [Marketing in social and cultural services and tourism]. SPb.: Piter, 480 p. (in Russian)

10. Sheremet'eva V.N. (2005) Segmentirovaniye v pryamom marketing [Direct Marketing Segmentation]. Rossiyskoye predprinimatelstvo - Russian business, no. 3, p. 25-29. (in Russian)

\section{ТЕХНОЛОГИЯ КОМПЛЕКСНОГО МАРКЕТИНГОВОГО ИССЛЕДОВАНИЯ ПРИ ЦЕЛОСТНОМ УПРАВЛЕНИИ ПОТРЕБИТЕЛЬСКОЙ ЦЕННОСТЬЮ ЖЕЛЕЗНОДОРОЖНЫХ ПАССАЖИРСКИХ ПЕРЕВОЗОК}

Низкая эффективность мероприятий, предпринимаемых для повышения качества обслуживания и удовлетворенности клиентов железной дороги, подтолкнула к поиску отличных от существуюших методов изучения пассажсиров, их запросов, способов удовлетворения. Обоснована потребность в развитии имеющейся методологии маркетинговых исследований. Подана усовершенствованная технология комплексного маркетингового исследования рынка железнодорожных пассажирских перевозок с учетом особенностей предлагаемых на нем услуг. Для нужд иелостного управления потребительской цеенностью таких услуг сегментирование транспортного рынка рекомендовано проводить методом «k-сегментирования». Метод адаптирован к отраслевой специфике и развит за счет предложения новых признаков сегментации. Преимущества и эффективность разработанной методики при формировании потребительской ценности транспортной услуги доказань на конкретном примере.

Ключевые слова: железнодорожный пассажирский транспорт, методология маркетинговых исследований, технология комплексного маркетингового исследования, сегментация пассажиров, признаки сегментации, потребительская ценность транспортной услуги, преимущества и ущемления пассажиров.

\section{TECHNOLOGY OF INTEGRATED MARKETING RESEARCH AT THE TOTAL CONTROL OF THE CONSUMER VALUE OF RAILWAY PASSENGER TRANSPORTATION}

Improving the quality of service and satisfaction of rail passengers has become a top priority for the passenger sector of the industry today. This significantly increased the requirements for the content, volume, relevance of information based on which management decisions are forms and made. The poor efficiency of the measures taken to improve the 
service has pushed to find ways other than existing methods of studying consumers and their requests, as well as ways to satisfy them. The advanced technology of complex marketing research of the market of railway passenger transportation is presents, taking into account the peculiarities of its offered services, which ensures observance of fundamental principles of holistic management of the consumer value of services, starting from the stage of creating its preconditions and at each stage of production of transport service. Segmentation of the transport market as one of the most important stages of marketing research is recommended to be carried out according to the "post hoc» approach, within which the most «k-segmentation» method is most appropriate for the needs of holistic management of the consumer value of transport service for long-distance transportation. This method is industry-specific and has been develops to offer new features for passenger segmentation. With the help of k-segmentation, the most significant ones, which affect the volume and capacity of passenger traffic, are determined on the basis of pairwise correlations between traditional and new features of segmentation. Based on the developed method, the customers of the railway were groups according to the paired combinations of segmentation features. Strategic vectors of marketers' actions aimed at retaining passengers, intensifying their demand for additional services and enhancing their satisfaction have been identifies for the selected segments. Advantages and efficiency of the developed methodology for the formation of the consumer value of transport services with increased size and content that meets the expectations of consumers are proves by a specific example.

Key words: railway passenger transport, marketing research methodology, integrated marketing research technology, consumer segmentation, segmentation sign, consumer value of transport service, passenger benefits and disadvantages. 